University of Texas Rio Grande Valley

ScholarWorks @ UTRGV

\title{
Ophthalmic Manifestations of Congenital Zika Syndrome in Colombia and Venezuela
}

\author{
Juan B. Yepez \\ Felipe A. Murati \\ Michele Petitto \\ Carlos F. Peñaranda \\ J. Fernando Arevalo
}

See next page for additional authors

Follow this and additional works at: https://scholarworks.utrgv.edu/som_pub

Part of the Diseases Commons, and the Ophthalmology Commons

\section{Recommended Citation}

Yepez, J. B., Murati, F. A., Pettito, M., Peñaranda, C. F., de Yepez, J., Maestre, G., Arevalo, J. F., \& for The Johns Hopkins Zika Center. (2017). Ophthalmic Manifestations of Congenital Zika Syndrome in Colombia and Venezuela. JAMA Ophthalmology, 135(5), 440-445. https://doi.org/10.1001/

jamaophthalmol.2017.0561

This Article is brought to you for free and open access by the School of Medicine at ScholarWorks @ UTRGV. It has been accepted for inclusion in School of Medicine Publications and Presentations by an authorized administrator of ScholarWorks @ UTRGV. For more information, please contact justin.white@utrgv.edu, william.flores01@utrgv.edu. 


\section{Authors}

Juan B. Yepez, Felipe A. Murati, Michele Petitto, Carlos F. Peñaranda, J. Fernando Arevalo, and Gladys E. Maestre

This article is available at ScholarWorks @ UTRGV: https://scholarworks.utrgv.edu/som_pub/27 


\section{Ophthalmic Manifestations of Congenital Zika Syndrome in Colombia and Venezuela}

Juan B. Yepez, MD; Felipe A. Murati, MD; Michele Pettito, MD; Carlos F. Peñaranda, MD; Jazmin de Yepez, MD; Gladys Maestre, MD; J. Fernando Arevalo, MD; for The Johns Hopkins Zika Center

IMPORTANCE The ocular manifestations and sequelae of Zika virus infection are not well known. Recently, the World Health Organization changed the declaration of Zika as a public health emergency and designated the viral outbreak and related microcephaly clusters as a long-term program of work. This change indicates the urgent need to evaluate and document ophthalmic manifestations in patients for timely management of this disease. In addition, confirmation whether the public health problem in Brazil extends to other regions in South America is needed.

OBJECTIVE To report the ocular manifestations of congenital Zika syndrome with microcephaly in Colombia and Venezuela.

DESIGN, SETTING, AND PARTICIPANTS This prospective case series included 43 patients from 2 ophthalmic centers in Colombia and Venezuela who underwent evaluation from October 1 , 2015, through June 30, 2016, and were clinically diagnosed with congenital Zika syndrome. Twenty patients were Hispanic; 13, African; 8, white; and 2, Native American.

INTERVENTIONS Ophthalmic and systemic evaluations and serologic testing were performed on all infants. Patients underwent external ocular examination and dilated ophthalmoscopy. Serologic testing ruled out toxoplasmosis, rubella, cytomegalovirus, syphilis, and human immunodeficiency virus.

MAIN OUTCOMES AND MEASURES Ophthalmic manifestations of congenital Zika syndrome.

RESULTS Of the 43 patients included in this series ( 28 female and 15 male), the mean (SD) age at examination was 2.1 (1.5) months. The mothers of all the children had no ophthalmic findings and did not report ocular symptoms during pregnancy. All patients had bilateral ophthalmic manifestations. Optic nerve findings included hypoplasia with the double-ring sign, pallor, and increased cup-disc ratio in 5 patients (11.6\%). Macular abnormalities included mild to severe pigment mottling in 27 patients (63\%) and lacunar maculopathy in $3(6.9 \%)$. Chorioretinal scarring was present in 3 patients (7\%). Eleven patients (26\%) had a combination of lesions in the posterior pole. Five patients (12\%) were diagnosed with congenital glaucoma, characterized by the clinical triad of epiphora, photophobia, and blepharospasm; increased intraocular pressure; corneal clouding at birth; and buphthalmos. These data reveal that $12 \%(95 \% \mathrm{Cl}, 5 \%-24 \%)$ of cases of congenital Zika with microcephaly had anterior segment abnormalities and $88 \%$ (95\% Cl, 76\%-94\%) had important macular and optic nerve abnormalities. The visual sequelae of these ophthalmic manifestations remain unknown.

CONCLUSIONS AND RELEVANCE Congenital Zika syndrome in the current study had severe ocular abnormalities, and all patients had bilateral involvement. Ocular findings were focal macular pigment mottling, chorioretinal atrophy with a predilection for the macular area, congenital glaucoma and optical nerve hypoplasia, and optic disc abnormalities. Ophthalmic examination is recommended in patients with congenital Zika syndrome.

JAMA Ophthalmol. 2017;135(5):440-445. doi:10.1001/jamaophthalmol.2017.0561 Published online April 13, 2017.
CME Quiz at

jamanetwork.com/learning and CME Questions page 508
Author Affiliations: Author affiliations are listed at the end of this article.

Group Information: Members of The Johns Hopkins Zika Center are listed at the end of the article.

Corresponding Author: J. Fernando Arevalo, MD, Retina Division, Wilmer Eye Institute, Johns Hopkins University School of Medicine, $600 \mathrm{~N}$ Wolfe St, Maumenee 708, Baltimore, MD 21287 (arevalojf@jhmi.edu). 
$\mathrm{T}$ he Zika virus was isolated in monkeys in the Ugandan Zika forest in the $1940 \mathrm{~s}^{1}$ and identified in humans in the 1950s in Africa. ${ }^{2}$ For most of the 21st century, Zika virus infection was extremely rare outside Africa. This relative obscurity was attributable to the lower prevalence and similarity of Zika virus infection to other more common mosquitoborne flaviviruses such as dengue and chikungunya. An epidemic of Zika virus occurred in Micronesia in 2007, which was the first outbreak outside Africa. ${ }^{3}$ The epidemic was considered to be benign because most of the infections (80\%) yielded only mild symptoms that were reminiscent of the betterknown dengue or chikungunya, including rash, fever, arthralgia, headaches, and conjunctivitis. The duration of symptoms generally ranged from 5 to 10 days, with no apparent long-term sequelae. ${ }^{3}$

More outbreaks of Zika virus occurred in the Pacific Islands region from 2013 to 2014. An epidemic in French Polynesia included the first published cases of Zika virus-related Guillain-Barré syndrome. ${ }^{4}$ By 2014, Zika virus had spread to South America, and an association with Guillain-Barré syndrome was reported in Brazil. ${ }^{5}$ In addition, the alarming new finding of cases of microcephaly was reported in the infants of Zika virus-infected mothers. ${ }^{6}$ The current scientific consensus is that Zika virus was the likely cause of microcephaly in these infants. ${ }^{7}$ Since May 2015, Zika virus has spread from South America to Central America, Puerto Rico, the United States, and the US Virgin Islands. More than 1 million cases of Zika virus infection have been reported in Central and South America. In addition, the neurologic manifestations of this viral infection are still evolving. Therefore, the World Health Organization declared Zika virus infection to be a Public Health Emergency of International Concern. ${ }^{8}$ However, in November 2016, the World Health Organization changed the declaration of Zika virus infection as a public health emergency and stated that the Zika virus outbreak and related clusters of microcephaly are no longer a Public Health Emergency of International Concern. This change in the declaration does not downgrade the importance of Zika virus but designates it as a focus for a long-term program of work. ${ }^{9}$

Diagnosis of Zika virus infection is problematic owing to the similar presentation of the virus to other flaviviruses, its self-limited nature, and its serologic cross-reactivity with other flaviviruses. Polymerase chain reaction assays can detect Zika virus RNA within the first week of infection but have limited usefulness beyond that time frame. Serologic testing for Zika virus IgM has high cross-reactivity with other flaviviruses. The plaque reduction neutralization test has greater specificity. ${ }^{10}$

In Colombia, a country with a population of 48 million, Aedes aegypti and Aedes albopictus mosquitoes are most commonly found at elevations below $2000 \mathrm{~m}$. A recent preliminary report by Pacheco et al $^{11}$ found that before April 2016, 65726 cases of Zika virus infection were reported in Colombia. Transmission of the Zika virus from mother to fetus and sexual transmission have been reported. The first outbreak of Zika virus infection in continental South America occurred in Brazil, where autochthonous transmission was confirmed in May 2015. Although preliminary monitoring began in Colombia after recognition of the Brazilian outbreak, the Colombian

\section{Key Points}

Question What are the ophthalmic manifestations in infants with microcephaly associated with clinically diagnosed Zika virus in Colombia and Venezuela?

Findings In this case series of 43 patients, substantial anterior and posterior segment abnormalities, including congenital glaucoma, were found in 5 (12\%) and macular or optic nerve abnormalities in $38(88 \%)$.

Meaning These findings suggest that all infants with microcephaly associated with clinically diagnosed Zika virus should undergo evaluation for ophthalmic findings.

Instituto Nacional de Salud began official surveillance for Zika virus infection in August 2015. ${ }^{11-14}$

In Venezuela, a country with a population of 30 million, a recent report by the Venezuelan Society of Public Health estimates that the number of probable cases of Zika virus infection from 2015 to the beginning of April 2016 was 723550 (23.6 per 1000 population), with hundreds of these cases occurring with Guillain-Barré syndrome. ${ }^{15}$ Although severe ocular complications have not been reported, tertiary ophthalmic clinics have observed severe multiple complications beyond typical conjunctivitis after symptomatic infection typical of the Zika virus. ${ }^{15,16}$ However, the prevalence of Zika virus infection in Colombia and Venezuela is still presumptive because definitive serologic testing for Zika virus was not available at the time. Therefore, the prevalence of Zika virus infection cited herein includes all the patients who were reported to the National Institute of Health in Colombia and Venezuela with symptoms of Zika virus infection with and without laboratory confirmation.

Microcephaly can be genetic, metabolic, drug related, or due to perinatal insults, such as hypoxia, malnutrition, or infection. The 20-fold increase in cases of microcephaly reported in parts of Brazil is temporally associated with the outbreak of Zika virus. However, this association is still presumptive because definitive serologic testing for Zika virus was not available in Brazil at the time of the outbreak and other causes of microcephaly may also have been mistakenly included. ${ }^{17}$ Other reports have been published on patients with Zika virus infection with ocular manifestations. ${ }^{17,18}$ An evaluation of 58 eyes in 29 infants by de Paula Freitas et $\mathrm{al}^{16}$ indicated bilateral findings in 7 of 10 patients with ocular lesions, with a prevalence of $34.5 \%$. Recently, a case of glaucoma in a patient with congenital Zika syndrome was reported. ${ }^{19}$ The objective of the present study is to report the ophthalmic manifestations in infants with congenital Zika syndrome in Maracaibo, Venezuela, and Cúcuta, Colombia.

\section{Methods}

This prospective case series evaluated 43 infants with congenital Zika syndrome at Clinica de Ojos in Maracaibo, Venezuela, and Clinica Oftalmológica Peñaranda in Cúcuta, Colombia. Ophthalmic evaluation was performed from October 1, 2015, through June 30, 2016. This study was approved by 
the institutional ethics committee at both study centers. Written informed consent for this study was obtained from the parents of all infants. The study and data collection adhered to the tenets of the Declaration of Helsinki. ${ }^{20}$

All infants and mothers underwent systemic and retinal examinations and documentation with fundus imaging. Inclusion criteria consisted of mothers with suspected Zika virus infection and a cephalic circumference of $32 \mathrm{~cm}$ or less at birth. Other congenital infections included in the differential diagnosis were TORCH, which includes toxoplasmosis, other infection (syphilis, varicella-zoster, or parvovirus B19), rubella, cytomegalovirus infection, and herpes simplex virus infection, and human immunodeficiency virus infection. These diseases were ruled out through serologic testing. In all cases, specific tests were performed as part of routine screening that included serologic testing of mothers. The suspected diagnosis of congenital Zika virus infection was also based on clinical features of the mothers during pregnancy, including cutaneous rash, fever, arthralgia, headache, itch, and malaise.

Newborn infants were excluded if they had a cephalic diameter that exceeded $33 \mathrm{~cm}$, evidence of other congenital infections such as TORCH or human immunodeficiency virus, or a familial history of microcephaly. All mothers underwent

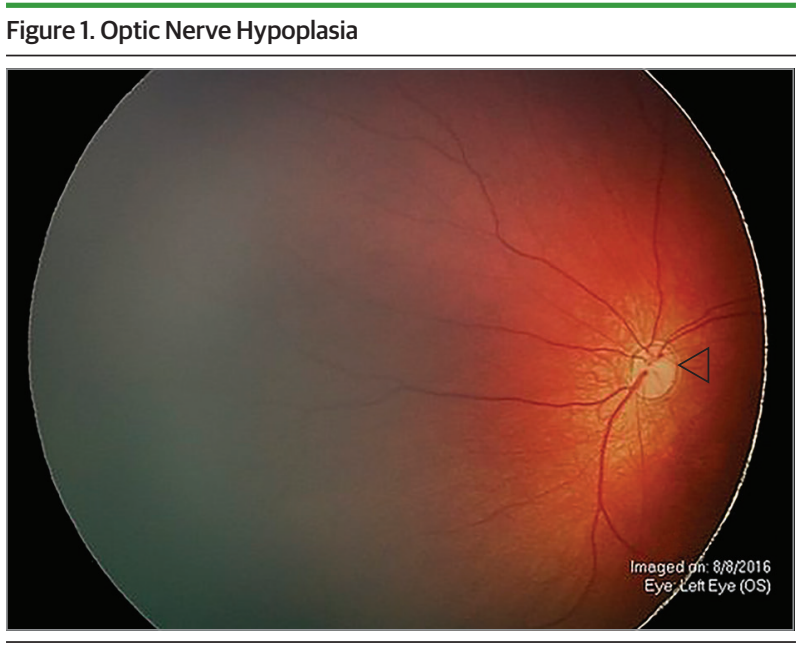

Representative ophthalmoscopy in the left eye of a patient with congenital Zika syndrome demonstrates optic nerve hypoplasia with the double-ring sign (open triangle) and disc pallor. an external ocular examination, biomicroscopy, and dilated indirect ophthalmoscopy. All infants underwent an ocular external examination and indirect ophthalmoscopy. Optic nerve, retinal, and choroidal abnormalities were documented with use of a wide-field digital imaging system (RetCam Shuttle; Clarity Medical Systems, Inc) after pupillary dilation.

Data were collected in an Excel 2011 spreadsheet (Microsoft Corp) and statistically analyzed with MedCalc software (version 8.2.0.3; MedCalc). Continuous data are presented as means and categorical data as numbers and percentages. $\mathrm{Pa}-$ tients' cup-disc ratio and corneal diameter were transferred from their records and converted to means for analysis. We used the paired $t$ test to compare mean values. Correlation was considered significant with $P<.05$. The $95 \%$ CIs were calculated using assumptions based on the Poisson distribution.

\section{Results}

Forty-three infants with microcephaly, ocular findings, and a clinical diagnosis of Zika virus vertical infection underwent evaluation. Mean (SD) age on the day of the examination was 2.1 (1.5) months (range, 0.2-6.6 months). Twenty-eight patients (65\%) were female, and 15 (35\%) were male. Twenty patients were Hispanic; 13, of African descent; 8, white; and 2, of Native American origin. All the patients were born during the Zika virus outbreak in Colombia and Venezuela, and all the mothers were clinically diagnosed with Zika virus infection, defined by denguelike symptoms (malaise, rash, and arthralgia) during pregnancy. Thus, the infants were clinically diagnosed with presumed intrauterine Zika virus infection (congenital Zika syndrome). Infants with microcephaly with a presumed diagnosis of congenital Zika syndrome were recruited through an active search and referrals from other hospitals and health centers. None of the mothers presented with any ocular findings. All infants presented with bilateral ocular findings. Five infants (12\%) had hypoplasia of the optic nerve with the double-ring sign, pallor, and increased cup-disk ratio (Figure 1). The macular abnormalities were mild to severe pigment mottling in 27 infants (63\%) (Figure 2) and lacunar maculopathy in 3 (7\%), defined as diffuse lacunar chorioretinal dysplasia. Chorioretinal scarring was present in 3 infants (7\%) (Figure 3). Eleven patients (26\%) had a combination of

\section{Figure 2. Severe Pigment Mottling}

A Patient A

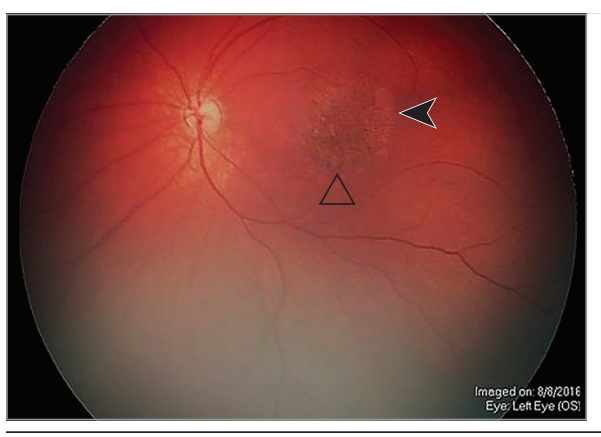

B Patient B

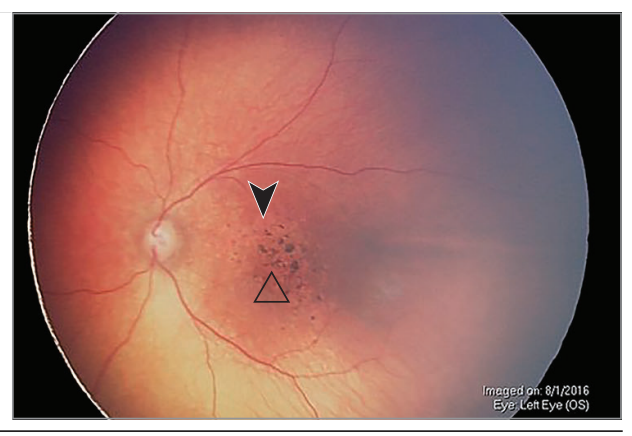

Representative ophthalmoscopy in the left eyes of 2 patients with congenital Zika syndrome demonstrates macular chorioretinal atrophy (open triangles) and focal pigment mottling (arrowheads). 
lesions in the posterior pole. Five infants (12\%) had congenital glaucoma characterized by the clinical triad of epiphora, photophobia, and blepharospasm; increased intraocular pressure to a mean of $57.4 \mathrm{~mm} \mathrm{Hg}$ (range, $49.8-76.1 \mathrm{~mm} \mathrm{Hg}$ ); corneal clouding at birth; and buphthalmos (enlargement of the eye) (Figure 4 and Table). In total, 12\% (95\% CI, 5\%-24\%) of cases had anterior segment abnormalities, and 88\% (95\% CI, 76\%-94\%) had important macular and optic nerve abnormalities. No other retinal manifestations were found. The retina remained attached in all cases. No cases of anterior uveitis were found in this series of patients.

\section{Discussion}

This study of the ophthalmic manifestations of congenital Zika syndrome found various abnormalities. These findings included focal pigment mottling with a predilection for the macular area, optic disc hypoplasia, lacunar maculopathy, and chorioretinal scars. In the present study, 5 infants presented with congenital glaucoma associated with Zika virus infection. To our knowledge, this case series is the first to report congenital glaucoma associated with congenital Zika syndrome. de Paula Freitas et al ${ }^{19}$ recently reported the first case of glaucoma associated with congenital Zika syndrome. Based on our findings, we agree with de Paula Freitas et $\mathrm{al}^{16}$ that all infants with microcephaly should undergo a routine ophthalmic examination, and every infant with microcephaly in countries with a high prevalence of Zika should undergo evaluation for abnormal ocular changes.

Zika virus is a mosquito-borne flavivirus transmitted by A aegypti and A albopictus, which are also vectors for dengue and chikungunya. The emergence of Zika virus worldwide, especially in tropical countries including Venezuela, coincided with increased reports of newborns with microcephaly, congenital malformations, and neurologic syndromes. The declaration on Zika virus by the World Health Organization in February 2016 was to the result of the rapid spread of Zika virus infection. Therefore, only cases with microcephaly were classified as presumed cases of congenital Zika virus infection and further investigated. ${ }^{16}$ A recent case report proposes that microcephaly should not be a required criterion for diagnosing congenital Zika virus infection. ${ }^{17}$
Zika virus infection causes a self-limited denguelike illness characterized by exanthema, low-grade fever, conjunctivitis, and arthralgia, although it may be asymptomatic in some cases. ${ }^{17,18}$ Some of the ophthalmic findings in the present study concur with those of previous reports. ${ }^{19,21,22}$ For example, chorioretinal scarring in the macular region has been reported in congenital Zika virus infection. ${ }^{17}$ de Paula Freitas et $a 1{ }^{16}$ described 17 eyes affected by Zika virus with microcephaly; ophthalmic findings included focal pigment mottling, chorioretinal atrophy, optic nerve abnormalities, iris coloboma, and lens subluxation. Our finding of congenital glaucoma in association with an epidemic of systemic disease is similar to the experience with congenital rubella syndrome. ${ }^{23} \mathrm{~A}$ follow-up study of 125 patients with congenital rubella syndrome ${ }^{23}$ evaluated the association between ophthalmic disorders and systemic disease and reported that $9 \%$ of the patients had congenital glaucoma. Transplacental transmission of West Nile virus has been previously reported, ${ }^{24}$ resulting in lesions somewhat similar to those described in the present study, such as macular granular appearance and chorioretinal scarring. The differential diagnosis of chorioretinal lesions such as those

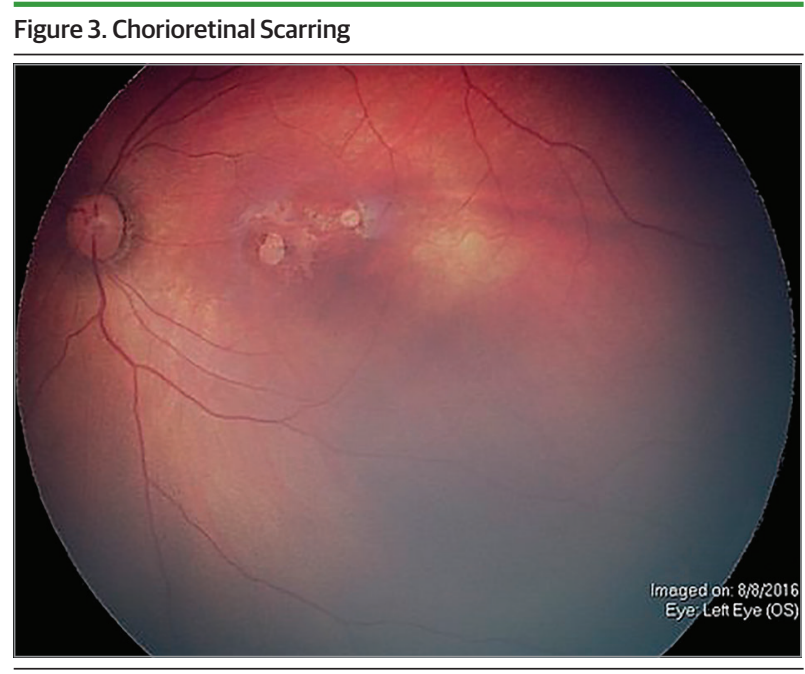

Representative ophthalmoscopy in the left eye of a patient with congenital Zika syndrome demonstrates a chorioretinal scar with macular retinal pigment epithelium hypopigmentation and scarce pigment surrounding 2 sharp areas of hypopigmentation (lacunae) with pigmentation in their borders and $250 \mu \mathrm{m}$ and $500 \mu \mathrm{m}$ in size.

\section{Figure 4. Bilateral Congenital Glaucoma}

A Right eye

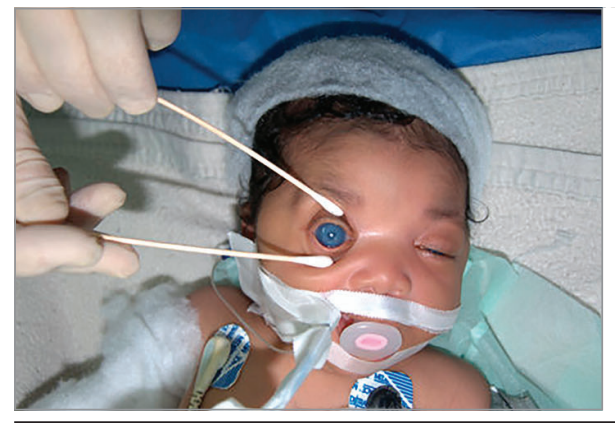

B Left eye

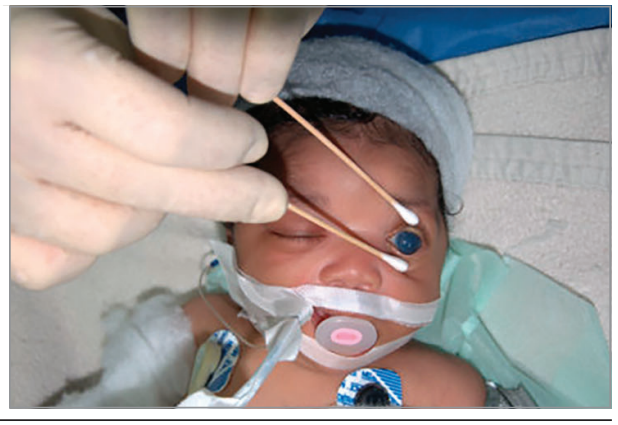

A patient with bilateral congenital glaucoma had the clinical triad of epiphora, photophobia, and blepharospasm; increased intraocular pressure; corneal clouding at birth; and buphthalmos in both eyes. 


\begin{tabular}{|c|c|c|c|c|c|c|c|c|c|}
\hline \multirow[b]{2}{*}{$\begin{array}{l}\text { Patient } \\
\text { No./Age, } \\
\text { mo }\end{array}$} & \multicolumn{5}{|l|}{ Examination } & \multicolumn{4}{|l|}{ 2-mo Follow-Up } \\
\hline & IOP, $\mathrm{mm} \mathrm{Hg}$ & $\begin{array}{l}\text { IOP During } \\
\text { Follow-up, } \\
\mathrm{mm} \mathrm{Hg}\end{array}$ & $\begin{array}{l}\text { Mean } \\
\text { Cup-Disc } \\
\text { Ratio } \\
\end{array}$ & Findings & Treatment & $\begin{array}{l}\text { IOP During } \\
\text { Follow-up, } \\
\text { Range (Mean), } \\
\mathrm{mm} \mathrm{Hg}\end{array}$ & $\begin{array}{l}\text { Corneal } \\
\text { Diameter, } \\
\text { Range } \\
\text { (Mean), mm } \\
\end{array}$ & $\begin{array}{l}\text { Mean } \\
\text { Cup-Disc } \\
\text { Ratio } \\
\end{array}$ & Findings \\
\hline $1 / 4.5$ & $\begin{array}{l}\text { OD, 44.5; } \\
\text { OS, } 46.4\end{array}$ & $\begin{array}{l}\text { OD, 13.1; } \\
\text { OS, } 13.0\end{array}$ & $\begin{array}{l}\text { OD, } 0.7 \\
\text { OS, } 0.7\end{array}$ & $\begin{array}{l}\text { Epiphora, } \\
\text { photophobia, } \\
\text { blepharospasm, no } \\
\text { anterior uveitis, and } \\
\text { corneal enlargement } \\
\text { and edema }\end{array}$ & $\begin{array}{l}\text { Combined } \\
\text { trabeculotomy } \\
\text { and } \\
\text { trabeculectomy }\end{array}$ & $\begin{array}{l}\text { OD, } \\
17.2-21.3 \\
(19.25) ; \\
\text { OS, 16.5-22.4 } \\
(19.45)\end{array}$ & $\begin{array}{l}\text { OD, } \\
12.9-12 \\
(12.45) \\
\text { OS, } \\
12.8-12.1 \\
(12.45)\end{array}$ & $\begin{array}{l}\text { OD, } 0.7 \\
\text { OS, } 0.7\end{array}$ & $\begin{array}{l}\text { Corneal scar and } \\
\text { haze, optic nerve } \\
\text { atrophy }\end{array}$ \\
\hline $2 / 3.1$ & $\begin{array}{l}\text { OD, } 49.8 \\
\text { OS, } 50.9\end{array}$ & $\begin{array}{l}\text { OD, } 12.2 \\
\text { OS, } 12.0\end{array}$ & $\begin{array}{l}\text { OD, } 0.7 \\
\text { OS, } 0.7\end{array}$ & $\begin{array}{l}\text { Epiphora, } \\
\text { photophobia, } \\
\text { blepharospasm, } \\
\text { no anterior uveitis, } \\
\text { buphthalmos, and } \\
\text { corneal enlargement } \\
\text { and edema }\end{array}$ & $\begin{array}{l}\text { Combined } \\
\text { trabeculotomy } \\
\text { and } \\
\text { trabeculectomy }\end{array}$ & $\begin{array}{l}\text { OD, } \\
12.4-17.4 \\
(14.9) ; \\
\text { OS, 13.6-16.1 } \\
(14.8)\end{array}$ & $\begin{array}{l}\text { OD, } \\
12-11.7 \\
(11.85) \\
\text { OS, } \\
11.9-11.5 \\
(11.7)\end{array}$ & $\begin{array}{l}\text { OD, } 0.7 \\
\text { OS, } 0.7\end{array}$ & $\begin{array}{l}\text { Corneal scar } \\
\text { and haze }\end{array}$ \\
\hline $3 / 6.6$ & $\begin{array}{l}\text { OD, } 76.1 ; \\
\text { OS, } 70.1\end{array}$ & $\begin{array}{l}\text { OD, } 13.0 \\
\text { OS, } 12.9\end{array}$ & $\begin{array}{l}\text { OD, } 0.8 \\
\text { OS, } 0.8\end{array}$ & $\begin{array}{l}\text { Epiphora, } \\
\text { photophobia, } \\
\text { blepharospasm, } \\
\text { no anterior uveitis, } \\
\text { buphthalmos, } \\
\text { corneal enlargement } \\
\text { and edema, and Haab } \\
\text { striae }\end{array}$ & $\begin{array}{l}\text { Combined } \\
\text { trabeculotomy } \\
\text { and } \\
\text { trabeculectomy } \\
\text { and } 1 \\
\text { IOP-lowering } \\
\text { medication }\end{array}$ & $\begin{array}{l}\text { OD, } \\
21.4-22.5 \\
(21.9) ; \\
\text { OS, 18.4-19.3 } \\
(18.8)\end{array}$ & $\begin{array}{l}\text { OD, } \\
12.5-12.5 \\
(12.5) ; \\
\text { OS, } \\
12.7-12.5 \\
(12.6)\end{array}$ & $\begin{array}{l}\text { OD, } 0.8 \\
\text { OS, } 0.8\end{array}$ & $\begin{array}{l}\text { Corneal scar and } \\
\text { haze, optic nerve } \\
\text { atrophy, Haab } \\
\text { striae }\end{array}$ \\
\hline $4 / 2.1$ & $\begin{array}{l}\text { OD, } 65.5 \\
\text { OS, } 46.7\end{array}$ & $\begin{array}{l}\text { OD, } 12.6 \text {; } \\
\text { OS, } 12.8\end{array}$ & $\begin{array}{l}\text { OD, } 0.7 \\
\text { OS, } 0.7\end{array}$ & $\begin{array}{l}\text { Epiphora, } \\
\text { photophobia, } \\
\text { blepharospasm, } \\
\text { no anterior uveitis, } \\
\text { buphthalmos, } \\
\text { corneal enlargement } \\
\text { and edema, Haab } \\
\text { striae, and optic disc } \\
\text { cupping }\end{array}$ & $\begin{array}{l}\text { Combined } \\
\text { trabeculotomy } \\
\text { and } \\
\text { trabeculectomy }\end{array}$ & $\begin{array}{l}\text { OD, } 16.8-21.2 \\
(19) ; \\
\text { OS, } 12.7-18.9 \\
(15.8)\end{array}$ & $\begin{array}{l}\text { OD, } \\
12.1-11.9 \\
(12.0) \\
\text { OS, } \\
12.4-12.3 \\
(12.35)\end{array}$ & $\begin{array}{l}\text { OD, } 0.7 \\
\text { OS, } 0.7\end{array}$ & $\begin{array}{l}\text { Corneal scar and } \\
\text { haze, Haab striae }\end{array}$ \\
\hline $5 / 1.8$ & $\begin{array}{l}\text { OD, } 51.1 ; \\
\text { OS, } 72.9\end{array}$ & $\begin{array}{l}\text { OD, 12.9; } \\
\text { OS, } 12.9\end{array}$ & $\begin{array}{l}\text { OD, } 0.7 \\
\text { OS, } 0.7\end{array}$ & $\begin{array}{l}\text { Epiphora, } \\
\text { photophobia, } \\
\text { blepharospasm, } \\
\text { no anterior uveitis, } \\
\text { buphthalmos, } \\
\text { corneal enlargement } \\
\text { and edema, and Haab } \\
\text { striae }\end{array}$ & $\begin{array}{l}\text { Combined } \\
\text { trabeculotomy } \\
\text { and } \\
\text { trabeculectomy }\end{array}$ & $\begin{array}{l}\text { OD, } \\
14.4-16.9 \\
(15.6) ; \\
\text { OS, 18.3-19.1 } \\
(18.7)\end{array}$ & $\begin{array}{l}\text { OD, } \\
12.7-12.6 \\
(12.65) ; \\
\text { OS, } \\
12.0-12.0 \\
(12.0)\end{array}$ & $\begin{array}{l}\text { OD, } 0.7 \\
\text { OS, } 0.7\end{array}$ & $\begin{array}{l}\text { Corneal scar and } \\
\text { haze, optic nerve } \\
\text { atrophy, Haab } \\
\text { striae }\end{array}$ \\
\hline
\end{tabular}

Abbreviation: IOP, intraocular pressure.

reported in this series includes many other infections, such as toxoplasmosis, cytomegalovirus infection, rubella, herpes simplex virus infection, and syphilis. However, these infections are easily ruled out with neonatal testing.

\section{Limitations}

Our study is limited by its retrospective nature and the fact that the mothers were clinically diagnosed as having Zika virus infection based on personal history. In addition, clinical criteria were used to diagnose Zika virus infection, and the diagnosis was presumptive. Furthermore, our study evaluated the ophthalmic manifestations in congenital Zika syndrome with microcephaly. Of note, microcephaly is not required for the diagnosis of congenital Zika syndrome. Therefore, ocular features may have been missed because of this exclusion criteria. However, the population sample of this study is representative of a random sample of the Colombian and Venezuelan populations living in hot and humid areas below an altitude of $2000 \mathrm{~m}$. Furthermore, these infants were born after a Zika virus outbreak in Colombia and Venezuela. This study presents previously unreported ocular findings in congenital Zika syndrome for the region.

\section{Conclusions}

Forty-three infants with congenital Zika syndrome had severe ocular abnormalities, and all patients had bilateral involvement. The posterior ocular findings were focal pigment mottling, chorioretinal atrophy with a predilection for the macular area, congenital glaucoma and optical nerve hypoplasia, and optic disc abnormalities. Our data revealed that $12 \%$ (95\% CI, 5\%-24\%) of cases of congenital Zika with microcephaly had anterior segment abnormalities and 88\% (95\% CI, 76\%-94\%) had important macular and optic nerve abnormalities. Ophthalmic examination is recommended in patients with congenital Zika syndrome.
ARTICLE INFORMATION

Accepted for Publication: February 22, 2017.

Published Online: April 13, 2017.

doi:10.1001/jamaophthalmol.2017.0561
Author Affiliations: Department of Vitreoretinal Surgery, Clínica de Ojos, Maracaibo, Venezuela (Yepez, Murati); Vitreoretinal Division, King Khaled Eye Specialist Hospital, Riyadh, Saudi Arabia (Yepez); Department of Glaucoma, Clínica de Ojos,
Maracaibo, Venezuela (Pettito); Clínica Oftalmológica Peñaranda, Cúcuta, Colombia (Peñaranda); Department of Pediatric Ophthalmology, Clínica de Ojos, Maracaibo, Venezuela (de Yepez); Division of Neurosciences, 
Department of Biomedical Sciences, University of Texas Rio Grande Valley School of Medicine, Brownsville (Maestre); Retina Division, Wilmer Eye Institute, Johns Hopkins University School of Medicine, Baltimore, Maryland (Arevalo); Johns Hopkins Zika Center, Johns Hopkins University School of Medicine, Baltimore, Maryland (Arevalo)

Author Contributions: Drs Arevalo and Yepez had full access to all the data in the study and take responsibility for the integrity of the data and the accuracy of the data analysis.

Study concept and design: Yepez, Murati, Pettito, Maestre, Arévalo.

Acquisition, analysis, or interpretation of data: Peñaranda, de Yepez, Maestre.

Drafting of the manuscript: Yepez, Murati, Peñaranda, de Yepez.

Critical revision of the manuscript for important intellectual content: Pettito, Maestre, Arévalo. Administrative, technical, or material support: Murati, Peñaranda, Maestre.

Study supervision: Yepez, Pettito, de Yepez, Arévalo.

Conflict of Interest Disclosures: All authors have completed and submitted the ICMJE Form for Disclosure of Potential Conflicts of Interest. Dr Arevalo reports receiving royalties from Springer SBM, LLC, nonfinancial support and consultancy from EyeEngineering, Inc, consultancy from Turing Pharmaceuticals, LLC, personal fees and consultancy from SECOND SIGHT, LLC, and personal fees and consultancy from DORC International BV, all of which were outside the submitted work. No other disclosures were reported.

Group Information: Members of The Johns Hopkins Zika Center at Johns Hopkins University, Baltimore, Maryland, include the following: Sheila West, PhD, PharmD (Department of Epidemiology/ Public Health); Noreen Hynes, MD, MPH, Thomas Quinn, MD, Anna Durbin, MD, and Adriana Andrade, MD (Department of Infectious Diseases); Jeanne Sheffield, MD, and Carolyn Sufrin, MD (Department of Maternal-Fetal Medicine); Christopher Golden, MD (Department of Neonatology); Mary Leppert, MD, Eliza Gordon-Lipkin, MD, Carlos PardoVillamizar, MD, Daniel Gold, MD, and Arun Venkatesan, MD (Department of Neurology); Carl Stafstrom, MD (Department of Pediatric Neurology); Thierry Huisman, MD, and Andrea Poretti, MD (Department of Pediatric Neuroradiology); William May, MD (director); Peter McDonnell, MD, J. Fernando Arevalo, MD, Rosane Ferreira, MD, Maria Carolina Marquezan, MD, Allen Eghrari, MD, Mandeep Singh, MD, Jennifer E Thorne, MD, Thomas McCarthy Bosley, MD, Rubens Belfort Jr, MD, Megan Collins, MD, Ashvini Reddy, MD, and Peter Gehlbach, MD (Department of Ophthalmology); Ranjit Varghese, MBBS (Department of Orthopedics); W. Christopher Golden, MD, and Kwang Sik Kim, MD (Department of Pediatrics); Frank Pidcock, MD (Department of
Pediatric Rehabilitation Medicine); Julie Quinn, PT (Department of Physiotherapy); Jennifer Payne, MD (Department of Psychiatry); Jason Brandt, PhD (Department of Psychology); Shirley Waite, LCSW-C (Department of Social Work); Anne Burke, MD (Department of Family Planning); and Valeria Canto-Soler, PhD, Lori Brando, PhD, Hongjun Song, PhD, Robert Yolken, MD, Heng Zhu, PhD, Brad Barnett, MD, and Melissa Olson, BS (Department of Basic Science).

Additional Contributions: We thank the mother of the patient shown in Figure 4 for granting permission to publish this information.

\section{REFERENCES}

1. Dick GW, Kitchen SF, Haddow AJ. Zika virus, I: isolations and serological specificity. Trans $R$ Soc Trop Med Hyg. 1952;46(5):509-520.

2. MacNamara FN. Zika virus: a report on three cases of human infection during an epidemic of jaundice in Nigeria. Trans R Soc Trop Med Hyg. 1954; 48(2):139-145.

3. Duffy MR, Chen TH, Hancock WT, et al. Zika virus outbreak on Yap Island, Federated States of Micronesia. N Engl J Med. 2009;360(24):2536-2543.

4. Oehler $E$, Watrin $L$, Larre $P$, et al. Zika virus infection complicated by Guillain-Barre syndrome: case report, French Polynesia, December 2013. Euro Surveill. 2014;19(9):pii:20720.

5. Brasil $P$, Sequeira $P C$, Freitas $A D$, et al. Guillain-Barré syndrome associated with Zika virus infection. Lancet. 2016;387(10026):1482.

6. Schuler-Faccini L, Ribeiro EM, Feitosa IM, et al; Brazilian Medical Genetics Society-Zika Embryopathy Task Force. Possible association between Zika virus infection and microcephaly: Brazil, 2015. MMWR Morb Mortal Wkly Rep. 2016;65 (3):59-62.

7. Mlakar J, Korva M, Tul N, et al. Zika virus associated with microcephaly. N Engl J Med. 2016; 374(10):951-958.

8. Gulland A. Zika virus is a global public health emergency, declares WHO. BMJ. 2016;352:i657.

9. World Health Organization. Fifth meeting of the Emergency Committee under the International Health Regulations (2005) regarding microcephaly, other neurological disorders and Zika virus. http://www.who.int/mediacentre/news/ statements/2016/zika-fifth-ec/en/. November 18, 2016. Accessed January 17, 2017.

10. Ventura CV, Maia M, Bravo-Filho V, Góis AL, Belfort R Jr. Zika virus in Brazil and macular atrophy in a child with microcephaly. Lancet. 2016;387 (10015):228.

11. Pacheco O, Beltrán M, Nelson CA, et al. Zika virus disease in Colombia: preliminary report [published online June 16, 2016]. N Engl J Med. doi: 10.1056/NEJMoa1604037
12. Calvet G, Aguiar RS, Melo AS, et al. Detection and sequencing of Zika virus from amniotic fluid of fetuses with microcephaly in Brazil: a case study. Lancet Infect Dis. 2016;16(6):653-660.

13. Foy BD, Kobylinski KC, Chilson Foy JL, et al. Probable non-vector-borne transmission of Zika virus, Colorado, USA. Emerg Infect Dis. 2011;17(5): 880-882.

14. Hills SL, Russell K, Hennessey M, et al. Transmission of Zika virus through sexual contact with travelers to areas of ongoing transmission: continental United States, 2016. MMWR Morb Mortal Wkly Rep. 2016;65(8):215-216.

15. Pan American Health Organization. Regional Zika epidemiological update (Americas) February 9. 2017: Zika virus-incidence and trends. http://www.paho.org/hq/index.php?option=com _content\&id=11599\&Itemid=41691. Accessed February 9, 2017.

16. de Paula Freitas B, de Oliveira Dias JR, Prazeres $\mathrm{J}$, et al. Ocular findings in infants with microcephaly associated with presumed Zika virus congenital infection in Salvador, Brazil [published online February 9, 2017]. JAMA Ophthalmol. doi:10.1001 /jamaophthalmol.2016.0267

17. Ventura CV, Maia M, Dias N, Ventura LO, Belfort R Jr. Zika: neurological and ocular findings in infant without microcephaly. Lancet. 2016;387(10037): 2502.

18. Lucey DR, Gostin LO. The emerging Zika pandemic: enhancing preparedness. JAMA. 2016; 315(9):865-866.

19. de Paula Freitas $B$, Ko Al, Khouri R, et al. Glaucoma and congenital Zika syndrome. Ophthalmology. 2017;124(3):407-408.

20. World Medical Association. World Medical Association Declaration of Helsinki: ethical principles for medical research involving human subjects. JAMA. 2013;310(20):2191-2194. doi:10.1001/jama.2013.281053

21. Miranda HA II, Costa MC, Frazão MA, Simão N, Franchischini S, Moshfeghi DM. Expanded spectrum of congenital ocular findings in microcephaly with presumed Zika infection. Ophthalmology. 2016;123(8):1788-1794.

22. Ventura CV, Maia M, Ventura BV, et al. Ophthalmological findings in infants with microcephaly and presumable intra-uterus Zika virus infection. Arq Bras Oftalmol. 2016;79(1):1-3.

23. Givens KT, Lee DA, Jones T, Ilstrup DM. Congenital rubella syndrome: ophthalmic manifestations and associated systemic disorders. Br J Ophthalmol. 1993;77(6):358-363.

24. Alpert SG, Fergerson J, Noël LP. Intrauterine West Nile virus: ocular and systemic findings. Am J Ophthalmol. 2003;136(4):733-735. 